\title{
Edukasi dan Peningkatan Kesadaran dari Segi Kesehatan dalam Rangka Percepatan Pencegahan Penanganan Covid-19 pada Pedagang Pasar Kota Palangka Raya
}

\section{Education and Awareness Raising of Health in Accelerating COVID-19 Handling Prevention in Market Traders of Palangka Raya City}

\begin{tabular}{|c|}
\hline Fera Sartika 1 \\
\hline $\begin{array}{l}\text { Risqika Yuliatantri } \\
\text { Paramawidhita }{ }^{2^{*}}\end{array}$ \\
\hline Suratno 1 \\
\hline $\begin{array}{l}\text { 'Department of Medical Laboratory } \\
\text { Technology, } \\
\text { Muhammadiyah } \\
\text { Palangka Raya, Central Kalimakaraya, } \\
\text { Indonesia }\end{array}$ \\
\hline $\begin{array}{l}\text { 2Department of Pharmacy, Universitas } \\
\text { Muhammadiyah Palangkaraya, } \\
\text { Palangka Raya, Central Kalimantan, } \\
\text { Indonesia }\end{array}$ \\
\hline $\begin{array}{l}\text { email: } \\
\text { risqikayuliatantriparamawidhit } \\
\text { @gmail.com }\end{array}$ \\
\hline $\begin{array}{l}\text { Kata Kunci } \\
\text { Edukasi } \\
\text { Pedagang } \\
\text { Pencegahan penularan COVID-19 }\end{array}$ \\
\hline $\begin{array}{l}\text { Keywords: } \\
\text { Education } \\
\text { Market traders } \\
\text { Prevention of COVID-19 transmission }\end{array}$ \\
\hline $\begin{array}{l}\text { Received: December } 2020 \\
\text { Accepted: January } 2021 \\
\text { Published: February } 2021\end{array}$ \\
\hline
\end{tabular}

\begin{abstract}
Abstrak
Pedagang pasar merupakan masyarakat yang rentan atau orang-orang yang paling berisiko terinfeksi Coronavirus Disease (COVID-19), dimana adanya kegiatan transaksi antara penjual dan pembeli, sehingga sangat penting adanya kesadaran baik dari penjual atau pembeli untuk menerapkan langkah-langkah pencegahan yang dianjurkan oleh pemerintah. Sasaran kegiatan ini adalah para pedagang di Pasar Besar Kota Palangka Raya, Kalimantan Tengah. Tujuan kegiatan ini adalah terjadinya peningkatan pengetahuan dan kesadaran dari segi kesehatan dalam melaksanakan protokol kesehatan di pasar dalam rangka percepatan pencegahan penanganan COVID-19. Metode pelaksanaan dalam kegiatan ini dengan memberikan kuesioner, edukasi, serta pelatihan/demonstrasi dalam menerapkan protokol kesehatan di pasar, serta pembagian leaflet, masker dan hand sanitizer. Kegiatan pengabdian masyarakat ini terfokus pada edukasi, sosialisasi dan pelatihan mengenai langkah-langkah penerapan protokol kesehatan di pasar terhadap 72 pedagang di pasar tersebut yang meliputi: (1) menggunakan masker; (2) melakukan kebersihan tangan; (3) menghindari menyentuh area wajah, (4) menerapkan etika batuk atau bersin dengan benar; dan (5) menjaga jarak (minimal 1 meter) ketika berinteraksi dengan pembeli/pedagang lain.
\end{abstract}

\begin{abstract}
Market traders are the people most at risk of being infected with Coronavirus Disease (COVID-19). Transaction activities in the market between sellers and buyers are high, so awareness is very important to implement the COVID-19 preventive health protocol recommended by the government. The target of this activity is traders in the Pasar Besar City of Palangka Raya, Central Kalimantan. The purpose of this activity is to increase knowledge and awareness in implementing health protocols in the market in order to accelerate the prevention of handling COVID-19. The method of this activity is by conducting surveys through questionnaires, providing education and training/demonstrations in implementing health protocols in the market, and distributing leaflets, masks, and hand sanitizers. This community service activity focuses on education, socialization, and training/demonstration of the application of health protocols in the market for 72 traders in the market, which includes: (1) wearing masks; (2) perform hand hygiene; (3) avoiding touching the face area, (4) applying proper etiquette coughing or sneezing; and (5) maintaining a distance (at least 1 meter) from other buyers/traders.
\end{abstract}




\section{PENDAHULUAN}

Pada awal tahun 2020, dunia digemparkan dengan adanya wabah virus baru yaitu virus corona virus baru (SARS-CoV-2) yang menyebabkan penyakit Coronavirus Disease (COVID-19). Virus ini pada mulanya diketahui berasal dari Wuhan Tiongkok dan ditemukan pada akhir Desember tahun 2019 (Yuliana, 2020). Pada hari Rabu tanggal 11 Maret 2020 WHO menetapkan COVID19 sebagai pandemi global.

Data dari Johns Hopkins School merilis lebih dari 3.754.650 kasus positif COVID-19 secara global dengan 1.246.184 kasus dinyatakan pulih dari virus dan 263.861 kasus meninggal dunia. Di Indonesia kasus positif telah mencapai 12.438 kasus positif dengan 2.317 kasus dinyatakan sembuh dan 895 kasus dinyatakan meninggal dunia (Gugus Tugas Percepatan Penanganan COVID-19, 2020). Di Kalimantan Tengah sendiri per tanggal 13 Mei 2020 kasus positif telah mencapai 223 kasus dengan 141 kasus dalam perawatan, 71 kasus dinyatakan sembuh dan 11 kasus dinyatakan meninggal dunia (Media Center Gugus Tugas COVID-19 Kalimantan Tengah, 2020).

Dalam Operasi Penanganan COVID-19, Pemerintah RI telah membentuk Gugus Tugas Percepatan Penanganan COVID-19 yang diketuai oleh Kepala BNPB. COVID-19 dapat menular dari manusia ke manusia melalui kontak dekat dan droplet, bukan melalui transmisi udara. Orang-orang yang paling berisiko terinfeksi adalah mereka yang berhubungan dekat dengan pasien COVID-19 atau yang merawat pasien COVID-19. Tindakan pencegahan dan mitigasi merupakan kunci penerapan di pelayanan kesehatan dan masyarakat. Langkah-langkah pencegahan yang paling efektif di masyarakat meliputi: melakukan kebersihan tangan menggunakan hand sanitizer jika tangan tidak terlihat kotor atau cuci tangan dengan sabun jika tangan terlihat kotor; menghindari menyentuh mata, hidung dan mulut, terapkan etika batuk atau bersin dengan menutup hidung dan mulut dengan lengan atas bagian dalam atau tisu, lalu buanglah tisu ke tempat sampah, pakailah masker medis jika memiliki gejala pernapasan dan melakukan kebersihan tangan setelah membuang masker dan menjaga jarak (minimal $1 \mathrm{~m}$ ) dari orang yang mengalami gejala gangguan pernapasan (Kementerian Kesehatan Republik Indonesia, 2020).

Kegiatan mendistribusikan barang dan jasa dilakukan oleh produsen, distributor, agen dan pedagang. Pedagang mendistribusikan barang dan jasa langsung ke konsumen dan pada umumnya kegiatan pendistribusian dilakukan di pasar. Pasar merupakan tempat pertemuan antara penjual dan pembeli. Dalam ilmu ekonomi pengertian pasar lebih luas daripada hanya sekedar tempat pertemuan antara penjual dan pembeli untuk mengadakan transaksi jual belibarang/jasa. Pasar mencakup keseluruhan permintaan dan penawaran, seluruh kontak atau interaksi antara penjual dan pembeli untuk mempertukarkan barang dan jasa (Indrawati \& Yovita, 2014). Pedagang pasar merupakan masyarakat yang rentan atau orang-orang yang paling berisiko terinfeksi COVID-19, dimana adanya kegiatan transaksi antara penjual dan pembeli, sehingga sangat penting adanya kesadaran baik dari penjual atau pembeli untuk menerapkan langkahlangkah pencegahan yang dianjurkan oleh pemerintah. Kegiatan pengabdian masyarakat yang mengusung tentang edukasi dan peningkatan kesadaran dari segi kesehatan dalam rangka percepatan pencegahan penanganan COVID-19 pada Pedagang Pasar perlu dilakukan dengan pertimbangan bahwa: 1) terus terjadinya peningkatan angka kasus positif COVID-19 di Indonesia; 2) hasil survey awal terkait dengan lokasi yang rawan penularan COVID-19 khususnya para pedagang yang berjualan di pasar; dan 3) rendahnya 
kesadaran masyarakat untuk menerapkan Protokol Kesehatan.

\section{METODOLOGI}

Metode pelaksanaan kegiatan pengabdian kepada masyarakat ini dilakukan terhadap 72 pedagang pasar di Pasar Besar Kota Palangka Raya, Kalimantan Tengah. Pelaksanaan kegiatan ini meliputi beberapa tahapan, yaitu persiapan, pelaksanaan pendampingan dan evaluasi program.

1. Tahap Persiapan

Tahap persiapan meliputi survey lapangan, wawancara, persiapan alat dan bahan.

a. Survei lapangan, dilakukan dengan mendatangi para pedagang yang berjualan di pasar besar kota Palangka Raya.

b. Persiapan alat dan bahan.

2. Tahap Pelaksanaan Pendampingan

a. Survei dengan menggunakan lembar kuesioner terkait pelaksanaan protokol kesehatan di pasar yang diajukan ke pedagang pasar.

b. Edukasi dan Sosialisasi, dilakukan dengan melakukan ceramah dengan media leaflet dan tanyajawab tentang protokol kesehatan yang bisa dilakukan pedagang saat bekerja di pasar.

c. Pelatihan dan Demonstrasi, dilakukan dengan melakukan pelatihan dan praktek langsung oleh tutor dan para pedagang dalam menerapkan protokol kesehatan.

d. Pembagian Leaflet, Alat Pelindung Diri (APD) seperti masker dan hand sanitizer kepada para pedagang.

3. Tahap Evaluasi

Evaluasi dilakukan terhadap seluruh tahap dalam kegiatan pengabdian kepada masyarakat ini, mulai persiapan, survei, edukasi \& sosialisasi, pelatihan \& demonstrasi, serta pembagian leaflet, hand sanitizer dan masker pada para pedagang pasar.

\section{HASIL DAN PEMBAHASAN}

Kegiatan pengabdian masyarakat ini dilakukan terhadap 72 pedagang di Pasar Besar Kota Palangka Raya, Kalimantan Tengah. Kegiatan ini dilakukan melalui beberapa tahapan sebagaimana pada Gambar 1, yaitu: (a) Survei terkait pelaksanaan protokol kesehatan di pasar, (b) Penyuluhan edukasi dan sosialisasi protokol kesehatan terkait penanganan COVID-19, (c) Pelatihan dan demonstrasi dalam menerapkan protokol kesehatan di pasar, dan (d) Pembagian leaflet, Alat Pelindung Diri (APD) seperti masker dan hand sanitizer (Gambar 1).

Survei terkait pelaksanaan protokol kesehatan di pasar dilakukan terhadap para pedagang untuk menggali informasi pengetahuan para pedagang terkait pelaksanaan protokol kesehatan. Selain identitas, kegiatan ini dilakukan untuk menggali pengetahuan dan wawasan pedagang terhadap penerapan protokol kesehatan di pasar dalam pencegahan COVID-19. Survei ini untuk mengetahui tingkat pengetahuan, sikap dan tindakan pedagang terhadap indikator-indikator penerapan protokol kesehatan yang bisa dilakukan di pasar oleh pedagang.

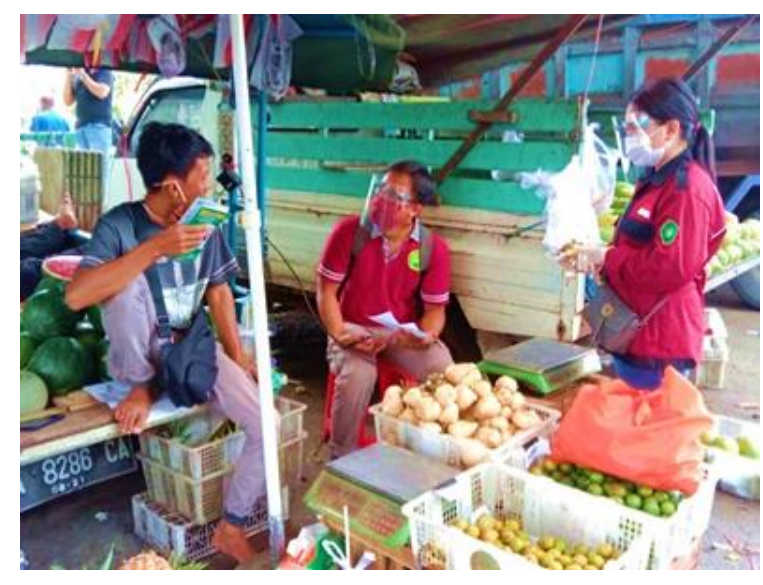

a 


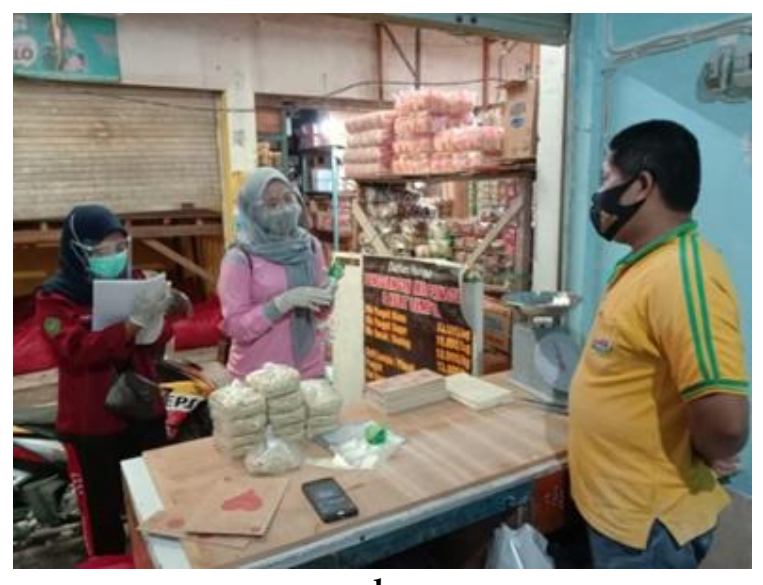

b

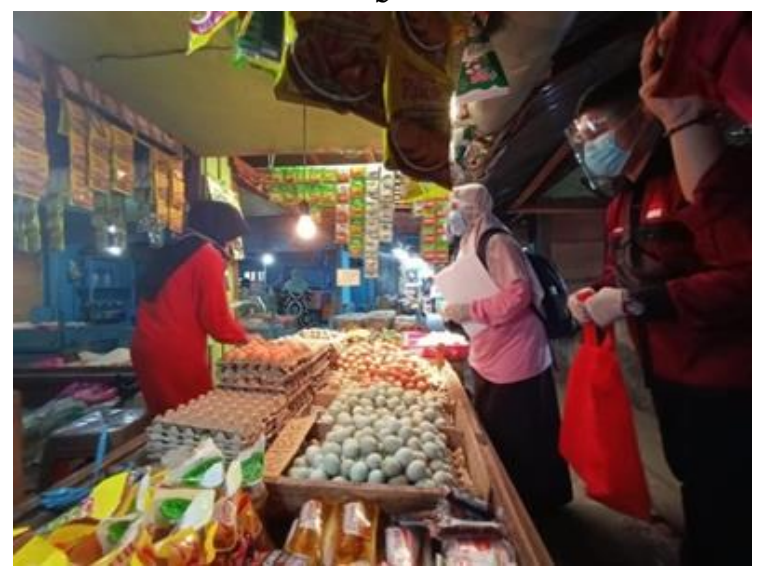

c

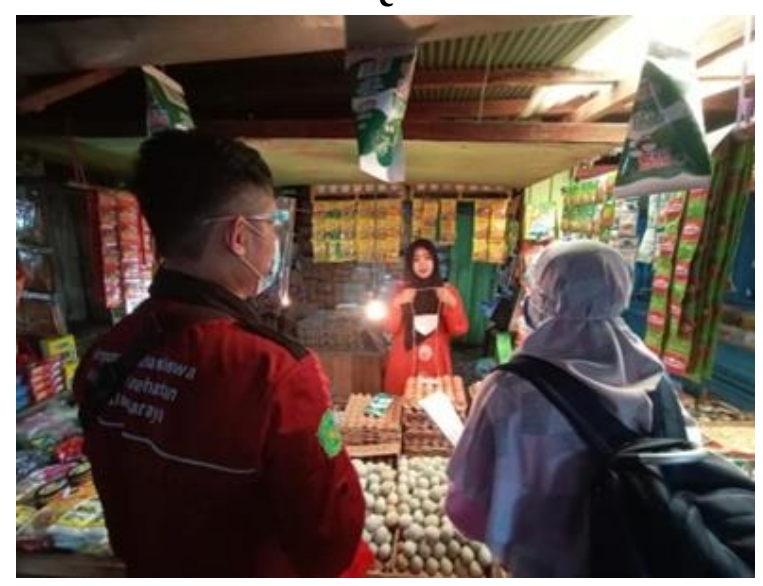

d

Gambar 1. Kegiatan pengabdian kepada masyarakat meliputi: (a) Survei, (b) Edukasi dan Sosialisasi, (c) Pelatihan dan demonstrasi, dan (d) Pembagian hand sanitizer dan masker

Adanya upaya menumbuhkan tingkat kesadaran pedagang melalui kegiatan sosialisasi, tim pengabdian kepada masyarakat juga melakukan survei terhadap kesadaran masyarakat khususnya pedagang dalam mencegah penyebaran COVID-19. Terdapat tiga aspek yang dilihat pada survei ini yakni, pengetahuan pedagang terhadap protokol kesehatan, sikap pedagang terhadap protokol kesehatan dan tindakan pedagang terhadap protokol kesehatan. Gambar 2 menjelaskan bahwa sebagian besar pedagang memahami tentang protokol kesehatan di pasar seperti memakai masker, mencuci tangan dengan sabun, menggunakan hand sanitizer, dan menjaga jarak. Namun, separuh dari pedagang yang memahami aspek menghindari menyentuh area wajah (mata, hidung dan mulut) dan menerapkan etika batuk yang benar. Hal ini menunjukkan bahwa separuh pedagang masih belum mengetahui bahwa dengan menyentuh area wajah dapat meningkatkan resiko penularan dari COVID-19, dikarenakan adanya kontak langsung antara tangan yang belum terjamin kebersihannya dengan area yang terbuka di wajah seperti mata, hidung dan mulut. Selain itu, separuh pedagang juga belum memahami terkait penerapan etika batuk yang benar. Hal ini menunjukkan bahwa masih banyak pedagang belum mengetahui bagaimana bahwa dengan tidak menerapkan etika batuk maka air liur (droplet) akan mengenai orang lain di sekitar sehingga dapat meningkatkan resiko penyebaran COVID-19. Sebagaimana yang dilaporkan oleh Girsang et al. (2020) bahwa pedagang pasar Karya Wisata Kelurahan Gedung Johor belum mendapatkan pengetahuan yang baik tentang pencegahan COVID-19.

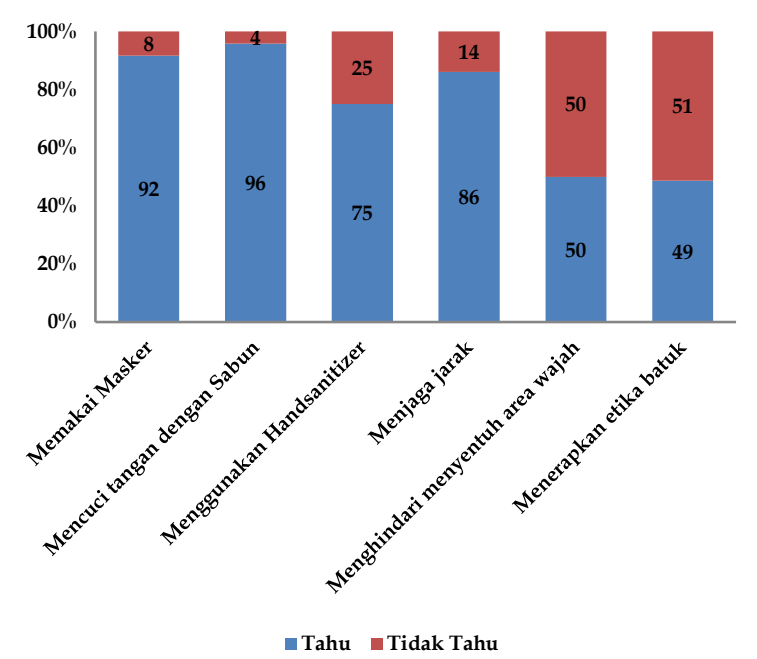

Gambar 2. Persentase pengetahuan pedagang terhadap protokol kesehatan 
Gambar 3 menunjukkan bahwa sebagian besar pedagang menyetujui dengan adanya penerapan protokol kesehatan terkait pencegahan COVID-19 di pasar. Sebagian besar pedagang di Pasar Besar Kota Palangka Raya setuju untuk menerapkan protokol kesehatan, seperti menggunakan masker, rutin cuci tangan, menggunakan hand sanitizer, menjaga jarak dengan pembeli, menghindari menyentuh area wajah serta menerapkan etika batuk adalah suatu usaha pencegahan yang harus dipatuhi oleh semua orang di masa pandemi.

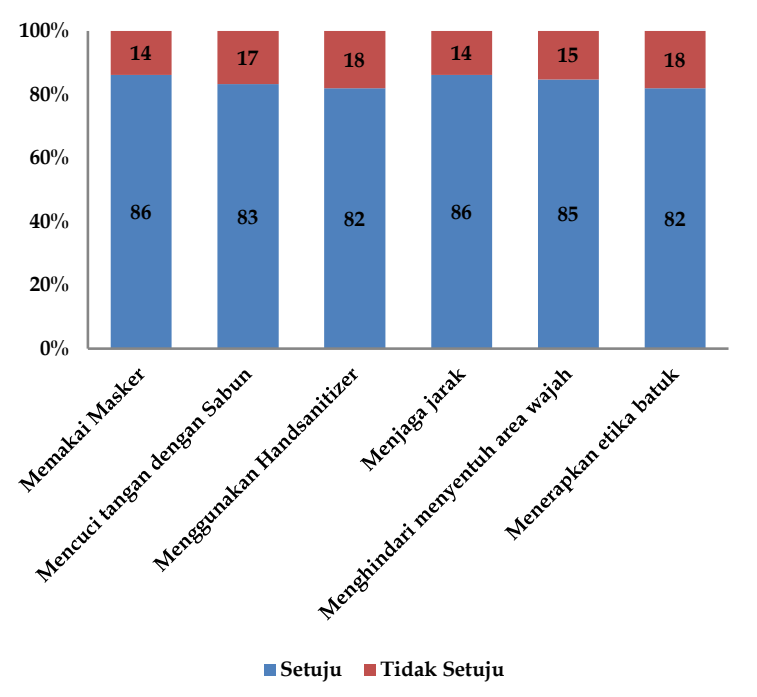

Gambar 3. Persentase sikap pedagang terhadap protokol kesehatan

Gambar 4 menunjukkan bahwa sebagian besar pedagang rutin menggunakan masker, mencuci tangan dengan sabun, serta menjaga jarak dengan pembeli/pedagang lain dalam penerapan protokol kesehatan di pasar dengan persentase masing-masing $68 \%, 72 \%$ dan $58 \%$. Hal ini lebihbaik bila dibandingkan dengan temuan Sembiring dan Suryani (2020) yang melaporkan bahwa sebagian besar pengunjung pasar tidak mematuhi protokol kesehatan dengan memakai masker saat bekerja. Rendahnya pedagang yang rutin menggunakan hand sanitizer yang hanya 39\% dapat dipahami karena penggunaan hand sanitizer sebagai alternatif selain mencuci tangan. Kurang dari separuh pedagang yang saat bekerja rutin menghindari menyentuh area wajah dan menerapkan etika batuk yang benar, bahkan hampir sepertiga pedagang tidak menerapkan dua aspek protokol kesehatan tersebut. Hal ini perlu menjadi perhatian bagi masyarakat karena aspek tersebut bisa meningkatkan penularan COVID-19. Salah satu kunci utama dalam menekan penyebaran COVID-19 adalah peningkatan kesadaran masyarakat.

Edukasi dan sosialisasi berupa ceramah dan tanya jawab terkait protokol kesehatan yang bisa dilakukan pedagang saat bekerja di pasar. Hal ini bertujuan untuk memberikan pemahaman dan pengetahuan terkait dengan hal-hal yang berhubungan dengan tindakan pencegahan COVID-19 khususnya di pasar. Selain itu juga untuk meningkatkan kesadaran masyarakat khususnya pedagang di Pasar Besar Kota Palangka Raya dalam rangka penanganan pencegahan penyebaran COVID-19. Menurut Pawiliyah et al. (2020), kegiatan sosialisasi terkait protokol kesehatan dapat meningkatkan pengetahuan dan kesadaran serta kepedulian pedagang dan pembeli dalam melakukan transaksi yang aman dalam upaya pencegahan dan memutus rantai penyebaran COVID- 19.

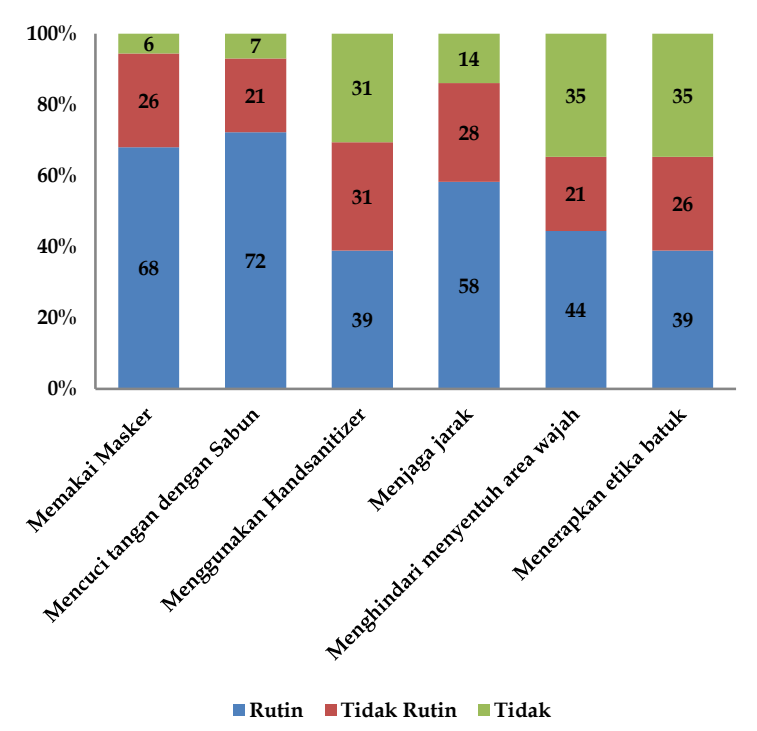

Gambar 4. Persentase sikap pedagang terhadap protokol kesehatan 
Pelatihan dan demonstrasi dilakukan dengan melakukan pelatihan dan praktek langsung oleh tutor dan para pedagang dalam menerapkan protokol kesehatan seperti: (1) menggunakan masker jika memiliki gejala pernapasan atau ketika berinteraksi dengan orang lain; (2) melakukan kebersihan tangan menggunakan hand sanitizer jika tangan tidak terlihat kotor atau cuci tangan dengan sabun jika tangan terlihat kotor sesuai dengan yang direkomendasikan oleh World Health Organization (WHO); (3) menghindari menyentuh mata, hidung dan mulut, (4) menerapkan etika batuk atau bersin dengan menutup hidung dan mulut dengan lengan atas bagian dalam atau tisu; dan (5) menjaga jarak (minimal 1 meter) ketika berinteraksi dengan pembeli/pedagang lain.

Pembagian Leaflet, Alat Pelindung Diri (APD) seperti masker dan hand sanitizer kepada para pedagang. Hal ini dilakukan untuk merangsang kesadaran para pedagang tentang pentingnya menjaga kebersihan tangan dan menggunakan masker saat berinteraksi dengan pembeli/pedagang lain. Menurut Sii et al. (2020), kegiatan pembagian masker dan hand sanitizer mampu memberikan kesadaran kepada masyarakat akan pentingnya menjaga kesehatan, dan penanggulangan penyebaran COVID-19. Menurut Suratno dan Nurhalina (2019), kegiatan pembagian Alat Pelindung Diri (APD) secara gratis dapat meningkatkan kesadaran masyarakat dalam melakukan upaya-upaya pencegahan terhadap penyakit.

Para pedagang sangat antusias dengan kegiatan pengabdian masyarakat ini, karena selain mendapatkan pengetahuan dan wawasan tentang pencegahan COVID-19 di pasar, mereka juga mendapatkan masker (reusable mask) dan juga hand sanitizer. Sebagaimana yang dilaporkan oleh Firdayanti et al. (2020), bahwa kegiatan seperti ini disambut antusias dan sangat bermanfaat bagi masyarakat.

\section{KESIMPULAN}

Kegiatan pengabdian kepada masyarakat ini meliputi survei, edukasi dan sosialisasi, pelatihan dan demonstrasi, serta pembagian leaflet, masker dan hand sanitizer kepada 72 (tujuh puluh dua) pedagang di Pasar Besar Kota Palangka Raya. Kegiatan pengabdian masyarakat ini terfokus pada edukasi, sosialisasi dan pelatihan mengenai langkah-langkah penerapan protokol kesehatan di pasar yang meliputi: (1) menggunakan masker; (2) melakukan kebersihan tangan; (3) menghindari menyentuh area wajah, (4) menerapkan etika batuk atau bersin dengan benar; dan (5) menjaga jarak (minimal 1 meter) ketika berinteraksi dengan pembeli/pedagang lain. Kegiatan pengabdian kepada masyarakat seharusnya digalakkan oleh setiap lini masyarakat, baik masyarakat maupun dinas-dinas terkait dalam upaya meningkatkan pencegahan penularan virus COVID-19. Perhatian pemerintah terhadap kelompok masyarakat khususnya para pedagang yang berjualan dipasar ditingkatkan secara terus menerus agar meningkatnya kesadaran dari segi kesehatan pada pedagang untuk menerapkan aturan dari pemerintah dalam rangka Percepatan Pencegahan Penanganan COVID-19 di kota Palangka Raya.

\section{UCAPAN TERIMA KASIH}

Tim penulis mengucapkan terima kasih kepada Lembaga Penelitian dan Pengabdian Pada Masyarakat (LP2M) Universitas Muhammadiyah Palangkaraya yang telah mendanai kegiatan pengabdian ini sehingga terlaksana dengan baik dengan nomor 11.p/PTM.63.R7/LP2M/P/2020.

\section{REFERENSI}

Firdayanti, F., Al Kautzar, A.M., Taherong, F., Andryani, Z.Y., Saleha, S., Diarfah, A.D. 2020. Pencegahan Covid-19 Melalui Pembagian 
Masker Di Kelurahan Romang Polong Kabupaten Gowa. Jurnal Abdimas Kesehatan Perintis. 2(1):53-57.

Girsang, V.I., Harianja, E.S., Purba, I.E. 2020. Pencegahan Covid-19 Pada Pedagang Pasar Karya Wisata Kelurahan Gedung Johor. Jurnal Abdimas Mutiara. 1(2):206-213.

Gugus Tugas Percepatan Penanganan COVID-19. 2020. Protokol Percepatan Penanganan Pandemi COVID-19 (Corona Virus Disease 2019). Jakarta: Gugus Tugas Percepatan Penanganan COVID-19

Indrawati, T., Yovita, I. 2014. Analisis Sumber Modal Pedagang Pasar Tradisional Di Kota Pekanbaru. Jurnal Ekonomi. 22(1):1-8. http://dx.doi.org/10.31258/je.22.01.p.1-8

Kementerian Kesehatan Republik Indonesia. 2020. Pedoman Kesiapsiagaan Menghadapi Coronavirus Disesase (COVID-19). Jakarta: Direktorat Jenderal Pencegahan dan Pengendalian Penyakit (P2P).

Media Center Gugus Tugas COVID-19 Kalimantan Tengah. 2020. Gugus Tugas COVID-19 di Kalimantan Tengah. Palangka Raya: Media Center Gugus Tugas COVID-19 Kalimantan Tengah.

Pawiliyah, P., Fernalia, F., Adriansyah, F., Saleh, S., Yuliyanti, R. 2020. Sosialisasi Transaksi Jual Beli Aman Terhadap Covid 19Memasuki Fase New Normal Di Pasar Tradisional Kota Bengkulu. Jurnal Kreativitas Pengabdian kepada $\begin{array}{lll}\text { Masyarakat } & \text { (PKM). } & \text { 3(2):415-421. }\end{array}$ https://doi.org/10.33024/jkpm.v3i2.3340

Sembiring, R., Suryani, D.E. 2020. Sosialisasi Penerapan Protokol Kesehatan di Masa Pandemi dengan Pembagian Masker Kesehatan Kepada Para Pedagang dan Pengunjung Pasar Tradisional Pajak Sore Padang Bulan. Jurnal Abdimas Mutiara. 1(2):124-130.

Sii, P., Iku, P.F., Warung, Y.E., Danu, A.K., Nesil, A. 2020. Wujud Kepedulian Melawan COVID-19 melalui Kegiatan Pembagian 5.000 Masker dan Hand Sanitizer Kepada Masyarakat Di Pasar Puni Ruteng -Manggarai. Randang Tana: Jurnal Pengabdian Masyarakat 3(2): 93-99.

Suratno, Nurhalina. 2019. Edukasi Resiko Penularan Penyakit Melalui Sampah pada Pemulung
Sampah di Tempat Penampungan Sementara Kelurahan Bukit Tunggal Kota Palangka Raya. PengabdianMu: Jurnal Ilmiah Pengabdian Kepada Masyarakat. 4(2):141-148. https://doi.org/10.33084/pengabdianmu.v4i 2.964

Yuliana, Y. 2020. Corona virus diseases (Covid-19): Sebuah tinjauan literatur. Wellness and Healthy Magazine. 2(1):187-192. https://doi.org/10.30604/well.95212020 